\title{
The Rights of Victim in the Iranian Code of Criminal Procedure Act 2013
}

\author{
Ahmad Ahmadi ${ }^{1}$ \\ ${ }^{1}$ Department of Law, Mahabad Branch, Islamic Azad university, Mahabad, Iran \\ Correspondence: Ahmad Ahmadi, Department of Law, Mahabad Branch, Islamic Azad university, Mahabad, Iran. \\ E-mail: chako1359@yahoo.com
}

Received: June 16, 2016

Accepted: July 29, 2016

Online Published: August 4, 2016

doi:10.5539/res.v8n3p279

URL: http://dx.doi.org/10.5539/res.v8n3p279

\begin{abstract}
This study investigates the rights of victim in the light of developments in the Code of Criminal Procedure 2013 in Iran. The victim as one of the pillars of the criminal phenomenon has found its actual and certain situation in criminal policy of communities. Criminal researchers have focused most of their efforts on elements such as crime, offenders, and penalties. But the victim of a crime or crimes often also plays a role in the crime, has been forgotten. With the advent of the knowledge of the victim in recent decades and highlighting human rights issues through the adoption of international and regional documents and regulations on offenders and victims, the ground for serious attention to the position of victims in national criminal justice systems has been provided. Therefore, moral and material support of victims like predicting the Compensation Fund, psychological and medical support are seen in the Iranian Code of Criminal Procedure Act of 2013. This study aims to explain the legal grounds supporting the victims and review and analyze the effects of the rights of this vulnerable group.
\end{abstract}

Keywords: victim, the victim's rights, Code of Criminal Procedure Act of 2013

\section{Introduction}

While one side of crime is victim, but it has been ignored in criminal investigations and studied less than criminal. Victim has been neglected approximately half of the century in many societies and in the process of administration of justice. In the legal sphere, supporting victim is one of the themes of crime, which in recent decades has been followed the field of study victim (victimology support) favored by lawyers and criminologists in the world. In fact, his rights according to the victim's rights have been neglected. The efforts by the theorists of the field in the recent developments and taking appropriate measures to recognize the rights of victims in the criminal justice process are clear, so that their actions are seen in criminal law of various countries. And, nowadays, the necessity to support the victims is not secret. In Iran's Criminal Code, the legislator takes into consideration the victim with terms such as victim and the complainant and tried to recognize studies of the victim and identify him as an element in criminal law and legal writings. Paying attention to victims and vulnerable persons such as children, women and various forms of mental and physical diseases have come to the attention of policymakers and practitioners. This means that, in addition to conducting numerous research and studies in this regard, a number of laws and regulations such as the Code of Criminal Procedure Act of 2013 and Victims Support Act have been developed in line with scientific findings and in support of the victims according to the cultural contexts and our society.

\section{Legal Basis of Protecting the Victims}

\subsection{Faith-Based}

One of the most important principles of protecting the victims, aside from the basics is the foundation of philosophy and ideology. Religious teachings, as from oppression and oppressors, have confirmed the severity of disgust, yielding to tyranny and oppression are also forbidden. In addition, defense of the oppressed and helping them are is considered as a religious obligation. Qur'an in several verses invites to protecting the victims, for example Surah Anfal verse 72 says: “... If those (believers' immigrant) for the sake of their religion, they ask you for help, you need to rush to help them". 


\subsection{Supporting the Values}

Another fundamental principles of the protection of victims has the normative basis. On this basis, thinkers pointed to the scale of values in society and protecting the victims and assert that protecting security and values of a society are at the top issues of criminal law and, basically, are the fundamental aims of criminal policy because supporting those in need, especially the poor and the victims, are the values of the society and hence, their support is worth.

\subsection{Failure of Governments in the Prevention of Crime}

The failure of governments to prevent the criminal phenomenon is another manifestation of the principles of protection of victims. Others knows the origin of protecting the victims in the failure of government in prevention of crime as well. In this regard, Raymond Gosen states: "The movement to protect the victims has been formed as the result of disability of Western societies in continuous growth and rising delinquency in the last thirty years as lack of power to act related to crime is the only solution to protect the victims and mitigate the impact of criminal phenomena."

According to this theory, the basis to protect the victim is the government's failure because, without doubt, one of the main objectives of governments is to create order and protect the safety, rights, liberty and life of citizens.

\subsection{Prevention of Crime}

According to this perspective, some thinkers believes that even if victims have a role in the realization of their crime and victimization, their support is very rational and worthy. The protection of victims has sought to reduce delinquency. On one hand, the protection and security losses, he misdemeanor repeated injuries resulting from the disability and victimization in his first seems immune. On the other hand, support and supply losses protect him from the repeated victimization and victimization resulting from his first inability and victimization. On the other hand, prevents a person from reprisals and arbitrary actions and the development of delinquency. On this basis, the protection of victims is one of the crime prevention methods. Studies have shown that, first, those who have been victimized once, they become victims of crime easily. Secondly, they need attention and support than other segments of society because damage to victims resulting from crime causes today victims become tomorrow's criminals. This is more noticeable in women and children.

\section{Effects of the Rights of the Victim in the Code of Criminal Procedure}

Code of Criminal Procedure Reform Act of 2013 with 2015 amendments in his first article, has offered to support the victim as one of the objectives of the legislation procedure. According to Article 1 of the Code of Criminal Procedure, victim rights are considered and states: "Criminal Procedure Code is a set of rules and regulations which are established for the discovery of crime ... and securing the rights of the accused, the victim and the community."

\subsection{Right of Awareness from Judicial Procedure}

Informing the victim of the changes in case, no need to his presence make them be more inclined to help in the research and judicial process. Paying attention to this has forced Iranian legislator to maintain the right to awareness of the preliminary investigation to the victim in Article 73 of the Code of Criminal Procedure 1999. According to this article, the victim can take a copy of the minutes of the preliminary investigation that is not inconsistent with the secrecy of the investigation. In other words, the victim access to the minutes of the preliminary investigation has been assigned to judge. Article 100 of the Code of Criminal Procedure 2013, in addition to the restatement of rule in Article 73 (1999), enjoys a tremendous advantage that is the duty of the investigating authorities to issue the subject of the lack of access to the file and mentioned the possibility of protest. Clause 1 of Article stated that: "At the request of the plaintiff, if the investigator knows the truth or access to all or some of the securities incompatible, he can refuse it with stating the grounds. Therefore, the plaintiff notified in person by a competent court within three days and this is objectionable. In addition, according to Article 38, the Law officers are also obliged to give him information about the case and the defendant's identity upon request of the victim."

\subsection{Right to Receive Medical-Emotional Services}

A direct consequence of crime, particularly violent and sexual crime, is the physical and emotional damage that is inflicted on the victim. In some cases, even the extent of emotional damage is much more harmful than physical injuries. Thus, one of the most basic needs of victims that is created immediately after the crime is medical and emotional needs. Higher principle of humanity requires that basic needs of the victim, even if the victim is at fault in crime, should be available as soon as possible. In addition to medical needs or perhaps more 
importantly are emotional needs which are felt to satisfy after the committing crime against them. Spiritual and emotional assistance to the victim can be effective in relieving the strain on him.

\subsection{Right to Protection against Damage}

Among those rights that are immediate result of the victim's right to respect for human dignity, are security for him and his witnesses. Since the victim can act as the best source of information on criminal incidents during law enforcement investigations and proceedings, hence, justice and fair proceedings depend upon the protection of the victim and witnesses against threats and vulnerabilities that may encounter them. It is worth noting in hedge arrangements referred to in Articles 132 to 147 of the Code of Criminal Procedure Act 1999, the possibility of adopting regulatory measures is not possible to ensure the safety of the victim, but in the Article 97 of Criminal Procedure Law of 2013 states: "Interrogator, to protect the victim, witnesses, informed, their families and the family of the accused against threats, if necessary, can take some precautionary measures to restrain order and justice." The very appropriate point in this article is that not only the victim but also protecting his family is also taken into account. Moreover, in order to provide greater protection of the victim, the investigating authorities and in some cases the court are obliged to adopt appropriate measures for the preservation of the victim's personal information.

\subsection{Right to Confidentiality of Victim's Identity}

Although such support cannot be found in the Iranian criminal procedure, but we can see a statement similar to this kind of support in Article 113 of the Criminal Procedure Act 1999. Although this clause to comply with the general trend of Iran's penal code has dealt with the expediency and pragmatism has paid but what is required in connection with the summons without cause, is the revealing of the victim's identity in order to prevent acts to limit the pressure on him/her. The confidentiality of the victim's identity supports his right to privacy. This can be found in Article 188 of the Criminal Procedure Act 1999.

Despite the decision to open trial in first and second paragraph of this Article excluded acts incompatible with chastity and Family Affairs with the request of the parties. And such cases are punishable. Article 101 of the Criminal Procedure Act 2013 requires that appropriate measures should be taken to prevent access to information about the victim and confidentiality of the victim's identity.

\subsection{Right to Access a Lawyer}

Including the victim's rights is the right to advice. Recommendations for understanding both criminal and civil cases, parties and various experts, differences in judicial process from complaint to compensation, related organizations, such as social security, insurance, commission of paying compensation to the victims and other social assistance and people like Relief Committee and the terms of the assistance are to be given. Of course, one of the assistances is to uphold the right of victims to enjoying the services of lawyers.

Thus, this is emphasized in the new Act. In accordance with Article 347, if the court deems necessary involvement of lawyers to the victim lacks financial ability, the court will appoint a lawyer for the victim. According to the lawyer as intermediary between the judiciary and the victim, he will be able to pursue due process and legal necessary measures. Thus, provisions of this Article of the Criminal Procedure Act 2013 are among those established in support of victims. In addition, Article 38 binds the officers of Justice to inform victims about the services available and other legal services.

\subsection{Right to Participate in Mediation}

Regulation of Article 195 of the Criminal Procedure Code in 1999, requiring the court to try to reclaim peace between the parties in the case can be considered in line with restorative justice in the judicial process. In this regard, Article 82 of the Criminal Procedure Act 2013 stipulates that the investigator or the prosecutor can achieve a compromise between parties subject to the agreement of the Council of dispute resolution or other person or entity referred to mediation. According to Article 83, in case of referral of the matter to mediation: "result of mediation in details and with the mediator and the parties reached an agreement to sign may be sent to the relevant judicial authority for review, approval, and further action. In case of reaching an agreement, the obligations of the parties and how to do them are required." Article 84 also provide enforcement mechanisms for mediation, the actions of institutions and individuals, and the adoption of regulations in this regard. 


\subsection{Right to Reparation}

Another guiding principles of criminal law is the principle of reparation to redress the mistakes. In the legal system Islamic Republic of Iran, Article 171 of constitution provides: "If the fault or error of the judge in the case or a case in the courts or in the implementation of the judgment, moral or material loss is noticed someone in case of fault blame redress and otherwise damage will be compensated by the government and in any case the defendant is rehabilitation".

However, the state compensation to victims has been provided in some cases specifically after the revolution and with the approval of the law of Hudud, Qisas and Diyat in 1982. This article of the constitution only at the stage of investigation and prosecution of compensation is recognized, but to compensation for unlawful arrest or detention not in principle there is no decree nor in other articles. Article 10 of the Law on compulsory insurance and compensation for state compensation can be loosely considered as physical damage fund administered under the supervision of the Central Insurance of Iran and the Central Insurance of Iran established by law passed in 1971. The idea of state compensation to victims in law oh Hudud, Qisas and Diyat in 1982 and IPC 1990 have revealed their effects and continued in the Penal Code, after the approval of the first and fourth books of the Penal Code in 2013 and was reconsidered. In addition to these crimes, the Armed Forces Act Article 41 of the Penal Code provides for the payment of blood money from the treasury. The victim's right to compensation in various materials is approved in Code of Criminal Procedure 2013, and it can be said that relatively comprehensive regulations guarantee this right and has been foreseen in the law. In this regard, Article 1 of the Law shall guarantee the rights of the victim at the stage of execution pointed out. According to Article 9 of the Code of Criminal Procedure existed in 1999-a crime could claim private claims for damages caused by the crime. Article 6 also guarantees and points out the rights of the victim in the judicial process, including the implementing the verdict. Also Articles 15, 16, 17 and 39 and numerous occasions have noted to observe the victim's right to compensation and the supervising arrangements governing it.

\section{Conclusion}

Protection of victims can play a major role and effective place in reducing criminal phenomena, realizing criminal justice, and providing moral and material damage in reconstruction his personality and spirituality. What has been entered in the area of victims' rights in criminal procedure adopted in 2013, is undoubtedly important step in this field. But, undoubtedly, the chance to achieve the aspirations of the international community facilities, at least at present, is not possible for us. Obviously, to achieve the desired welfare standards in the international community in connection with providing services to victims will take a long time in our country and, therefore, despite the efforts and follow-up, we are still in a relatively long distance from international standards. However, those stated in the Code of Criminal Procedure, are some of the rights of the victim in the criminal justice process; the selection of the dream and idealism tried to be avoided. The author aims at studying the rights of the victim at this stage in a very broad approach and numerous cases can be found as the right of the victim but the main goal is comparing Iran's domestic laws with such data.

In general, in relation to the protection of victims in the Code of Criminal Procedure, it must be noted that several clauses have been regulated in order to provide appropriate, adjusted ground so that it can meet the concerns of many victims. It is worth mentioning, specific victims' rights have been predicted including women and physically and mentally disabled and other vulnerable people. In the end, it is worth noting this bill, judicial and administrative infrastructure is required i.e., for the rights of the victim as an active and effective element in the process of criminal, judicial and executive authorities must be serious engagement. Also, at the macro level, both human and material resources necessary in order to fulfill the objectives of the Code of Criminal Procedure, including the rights of victims should be provided.

\section{References}

Abbasi, M. (2003). New horizons restorative justice in criminal mediation. Tehran, Press Journal.

Abdel-Fattah, E. (1992). The Politics of Crime Victims defense policy (A. H. N. Abrndabady \& S. Calligraphy, Trans.). Justice Law Journal, 3.

Bazyar, A. (2007). State compensation of victims' comparative study in Iran and England (MA thesis). Criminal Law and Criminology, University of Madras.

Dehabadi, H. (2006). A comparative study of victim compensation at the expense of the state and public institutions (Iran, Islam and the United Kingdom) (criminal law and criminology doctoral thesis). Shahid Beheshti University. 
Eskandari, A. (2008). Strategies for protecting the victims of Islamic criminal policy and international instruments. Knowledge Magazine, 134.

Gholami, H. (2006). Restorative justice. Tehran, Samt publisher.

Gosenn, R. (1991). Introduction to Criminology (S. Bthayy, Trans.). Tehran, publishing of Justice.

Mehra, N. (2008). Criminal justice system in England and Wales: Policies and procedures. Journal of Law and Jurisprudence, 16.

Najafi Abrandiabady, A. (2003). A restorative justice (1st ed., A. H. N. Abrndabady, Trans.). Tehran, the publisher.

Shiri, A. (2006). Restorative justice, foundations and activists, criminal law and criminology (doctoral dissertation). University martyr Beheshti.

Tavajohi, A. (1998). The victim in the criminal policy of Iran, criminal law and criminology (Doctoral thesis). Tarbiat Modarres University.

\section{Copyrights}

Copyright for this article is retained by the author(s), with first publication rights granted to the journal.

This is an open-access article distributed under the terms and conditions of the Creative Commons Attribution license (http://creativecommons.org/licenses/by/4.0/). 